\title{
The Ritual (Traditional) Songs In The Villages Of Tirana
}

\author{
Kreshnik Duqi, PhD Candidate
}

\section{doi: 10.19044/esj.2016.v12n20p12 ～URL:http://dx.doi.org/10.19044/esj.2016.v12n20p12}

\begin{abstract}
This work intends to reflect on and to analyze the rituals ever-present during the holidays and the traditional celebrations during the year. The stimulus for this study was the interest shown towards ritual songs, which with the passing of the time are being forgotten and fade away as a result of social and cultural development. In this study we intend to point out some general characteristics of the songs of the spring season, including important holidays and rituals such as: "The First day of Summer", "Llazoret (collecting eggs from the neighbors as a sign of spring coming)", "Saint George", etc; and also other songs which represent the traditional rituals related to agriculture and livestock farming to whom are dedicated specific ceremonies too. In this study we have analyzed some of these songs in order to better understand their origin and to reach some conclusions too. We found out that the song "Llazoret" is sung in different areas of Tirana's villages, but with some variations. The grouping of the songs used in this study testifies that the origin of these songs is very old. Outside the rituals these songs lost their original meaning and that's the reason why many of them are disappeared and the rest is dying slowly because of the obliteration.
\end{abstract}

Keywords: Ritual songs, artistic communication, traditional rituals, folklore

\section{The ritual/ceremonial songs in the villages of Tirana}

The ritual songs are songs that accompany celebrations and the traditional yearly holidays. Their sound is primitive; their lyrics unveil the soul of the Albanian people during the celebrations, their own lives, the traditions, the emotional state, and the desires in joyful days. These songs have short melodies and their origin is ancient.

But how to better understand the meaning of "ritual songs" and the word "Rite" in Albanian language? 
The entirety of the practices followed according to specific rule decided by the tradition, during special occasions of the daily life. ${ }^{1}$

Or, as defined by the English dictionary:

'An act or series of acts regularly repeated in a set precise manner'

The words and music in them are an integral part of the ritual actions. In our time many of these songs have been forgotten since the rituals are being forgotten too and these songs lose their real meaning outside the rituals. The traditional motifs and rituals are related to agriculture and livestock, where special rituals are dedicated to sowing, harvesting, threshing, rain, the flock on the mountain, milking, etc.

Spring is the season people look forward to, while winter is symbolized by a boring and melancholic nature. Spring symbolizes warmth, blossoming, happiness, etc. This season was welcomed by different rituals which symbolize the welcoming of the spring's sun that gives a start to happiness and vivacity.

The spring cycle includes celebrations and traditions for special days like "The First Day of Summer", "Llazoret (collecting eggs form the neighbors as a sign of spring coming)", and "Saint George's Day". When spring comes, grown up children, men, etc. go out during the late evening and knock from door to door to ask for eggs, and this is called "llazore"; they use the expression 'llazoret janë jashtë (llazores are out)', it means that spring is coming. Here are some of the songs that are sung in this celebration: "Llazore are on the wall”; "Llaxore, llaxore"; "Llaxoret". If you see carefully the titles of the songs above, we will find different versions of the Llazore's ritual, also in some other songs we find it written differently: sometimes with ' $\mathrm{x}$ ' and others with ' $\mathrm{z}$ '. This means that we have three different variations of the 'llazore'(a group of men and children wearing masks and asking for eggs from house to house was called 'llazore').

Another song mentioned and studied in this material is dedicated to the "Saint George’s Day": O Shëngjergj i nushullu (O blessed Saint George).

But, as we mentioned before, these celebrations, as the ones above, have lost the usual function and together with this the rituals and the songs dedicated and sung during these special days are being lost too.

Kush më zant' dillin (Who hid my sun) ${ }^{2}$

Tirana, 1976

Singer: Man

${ }^{1}$ www.fjalorishqip.com, rit.

${ }^{2}$ Hysen FILJA, "Folk Songs of the central Albania”, The Science Academy of The Socialist Republic of the People of Albania, The Institute of the Folk Culture, "Mihal Duri" Press, Tirana 1991, f 49, Song 14, Cassette 1086/33. 
Bob. 1086/33

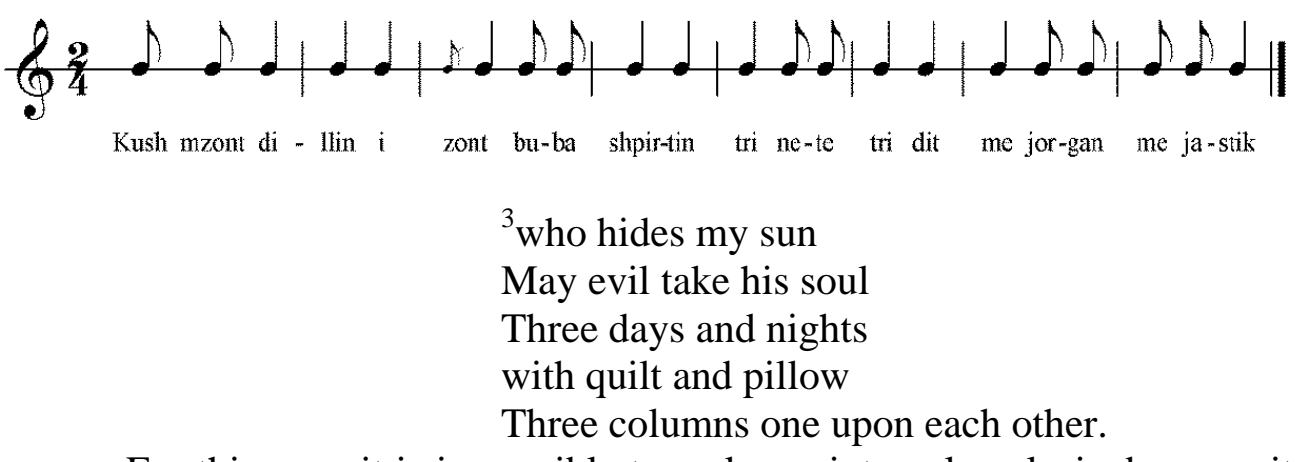

For this song it is impossible to make an interval analysis, because it is a musical composition with only one sound.

About this division, we must emphasize the fact that upon

a single note you can play a certain rhythmic scheme, but we cannot make a melody. ${ }^{4}$

It has been built in a binary metric (2/4) and three rhythm sounds overlapping each other. $(\Lambda \Omega \downarrow),(d),(d \Omega \Lambda)$.

By comparing the score with the lyrics we see a change of the dialect (m'zont - më zant') and the conjunction "e” (meaning and) has been added. In the musical transcription the last verse could have been shown too.

The bread (Buba) keeps alive the soul of the people, so the bread is life. The philosophy of the people and of the humans since cretion has been that the sun-the symbol and the source of life, is above everything else. Without the sun there is no food (bread), meaning that the human beings wouldn't be able to survive. A human curses the person who blocks the sun; we see this in the second line "may evil take your soul". Without the sun life is even harder in winter, especially for the people who were living in the cages, or in shacks.

O Shëngjergj i nushullu ${ }^{5}$

Tirana, 1976

Singer: Ismail Dashi (we have no information about this man who sings this song)

Bob. 1286/27

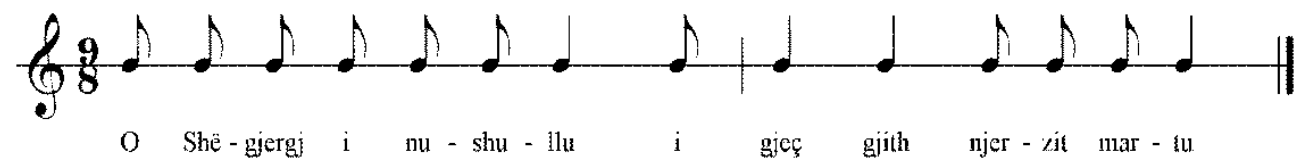

\footnotetext{
${ }^{3}$ The music of this song has been collected by H. Filja and the writing in notes by H. Filja.

${ }^{4}$ V.S. Tole "Albanian musical folklore", Iso polyphony and Monody, "Uegen”, Tirana, 2007.

${ }^{5}$ Hysen FILJA, "Folk Songs of the central Albania”, The Science Academy of The Socialist Republic of the People of Albania, The Institute of the Folk Culture, "Mihal Duri” Press, Tirana 1991, f 49, Song 14, Cassette 1286/27.
} 
${ }^{6}$ O blessed Saint George ${ }^{7}$

8

may you find everyone married.

In this song as in the one before we can't make an interval analysis because in this song, the melody it has been built on only one pitch; it has the meter $9 / 8$ and the notes values are eighth-note and quarter-note.

We had the chance to listen to this song and in the cassette recording we heard that these two lines are repeated twice, but the most interesting thing is that in the second line the word "people" in the cassette recording is changed into "gypsies". Maybe the reason for the change was to avoid racism.

Saint George is the symbol of spring, of joy, and we sing to that in Central Albania and especially in the villages where people were of mixed religious background, so it is more a non religious celebration. And the most meaningful wish given to the couple who is getting married is the continuity of life.

Marsi karsi (March, Karsi) ${ }^{9}$

Tiranë, 1976

Singer: Man

Bob. 1286/34
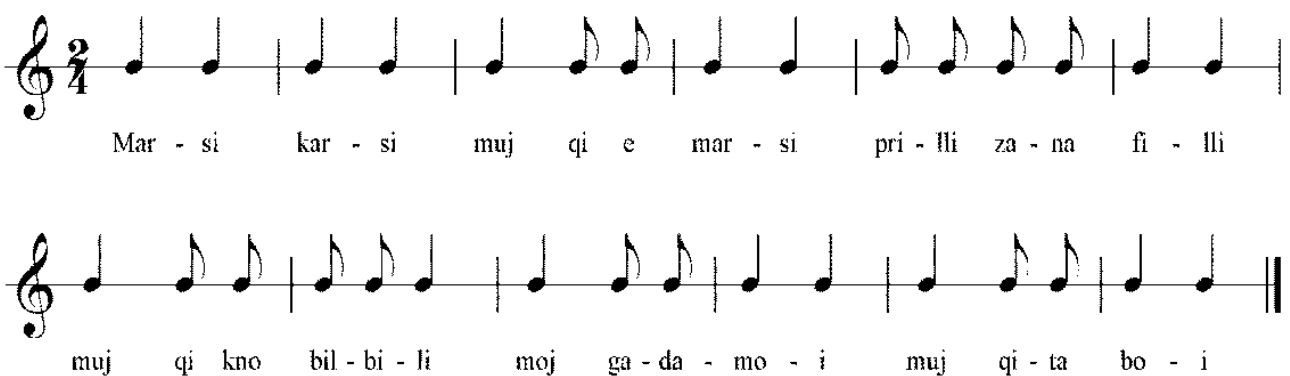

${ }^{10}$ March, Karsi ${ }^{11}$

the month when I got pregnant

April - Beginning

When the nightingale sings

\footnotetext{
${ }^{6}$ Music and lyrics collected by H. Filja

${ }^{7}$ Yearly traditional folk celebration, especially in spring.

${ }^{8}$ Bringing the happy news that spring is near.

${ }^{9}$ FILJA Hysen, "Folk Songs of the central Albania”, The Science Academy of The Socialist Republic of the People of Albania, The Institute of the Folk Culture, "Mihal Duri” Press, Tirana 1991, f51, Song 16, Cassette 1286/34.

${ }^{10}$ Music and lyrics are collected by H. Filja. Written in notes by H. Filja.

${ }^{11}$ These verses where sung after March was over to show that together with it, the winter was gone too.
} 
This song just like the other two above is a musical monophonic musical creation and we can't analyze the interval, the melody or the mode. These songs sound like you recite poetry more than sing a song.

This song has a short strophe made of four lines and we notice that every line has a different number of syllables. The first one has four syllables, the second line has five syllables, the third one has six syllables and the fourth has eight syllables. So, from one line to the other we see additional syllables added.

This material is built by dividing one line of the lyrics into two measures, and the first two measures have two quarter-notes each. Later the quarter-notes of four become eighth -notes depending on the syllables of the line. This is more often in the odd number of measure 1,3,5,7,9,11. At the others the notes remain with the quarter-notes except for the word 'nightingale' where the first quarter-note is divided in two eighth-notes.

When we see the partiture we find out that there are two more missing lines, with five syllables each.

$$
\text { May - Gadamoi }
$$

When I will give birth

In this song we find the northern dialect. March is the beginning of spring and we see the first signs of it (at least in south Albania because in the north might be still snow and winter). During April these spring signs are even more evident all over the country and the vitality of life is obvious, but May is the triumph of nature over winter. These are the three main moments of spring.

This is the first overview given by the lyrics of this song, simple words that declare the spring coming. This is the definition written for this song when it was published. While I was sharing this song with some elderly people, one of them laughed and said: "This song's history and meaning are deeper than you think."

Because of his old age he couldn't sing it to us, but he remembered the lyrics and even the history.

The lyrics of this song tell the story of a woman who got married but in the mean time she was pregnant. After some time her husband started to have doubts and was wondering why the baby was born early and not after 9 months. So, he began to ask questions to his wife.

His wife was very smart so she starts counting the months. At the first line "Marsi - karsi (Marsi - March; Karsi - it is an fiction month, it doesn't really exist)" she counts two months in one, the first one is March and the second one is Karsi; the second line "muji qi e marsi (the month that impregnated)" completes the first line telling her husband that this is the month when she got pregnant. 
She keeps counting the months at the third line "Prilli Zanafilli (April - Beginning)" April is the fourth month and Beginning is the fifth (she pretends Beginning is the name of a month). The fourth line completes the other ones showing the symbol of spring which is the song of the nightingale. She keeps counting the months and at the fifth line "MoiGadamoi (May - Gadamoi)" she says May is the sixth month and Gadamoi according to her is the seventh month. The fifth line "muji qi ta boj (the due month)" also completes the meaning of the other verses and it means that is the month when the baby was born.

By counting the months this way she could count seven months and she hides the truth by saying that the baby was born prematurely.

From this point of view, the song has a totally different meaning than the one we thought before. If we read the lyrics of this song once again, we completely understand each of the lines. People say this is the real meaning of this song. The lines that confirm this meaning is the last one: "muj qi $e$ marsi (the month that impregnated)" which shows that she got pregnant during this month, and the last one "muji qi ta boj (the due month)" which tells us when the baby was born. (This story was told during an interview in Albanian language, on 2016. This person wanted to remain anonymous.)

\section{Llazoret po rrin ke muri (Llazore are standing at the wall) ${ }^{12}$ Fikas, Tirana, 1974 \\ Singer: Muharrem Bakalli (This man was born on 1934)}

Bob 1051/14

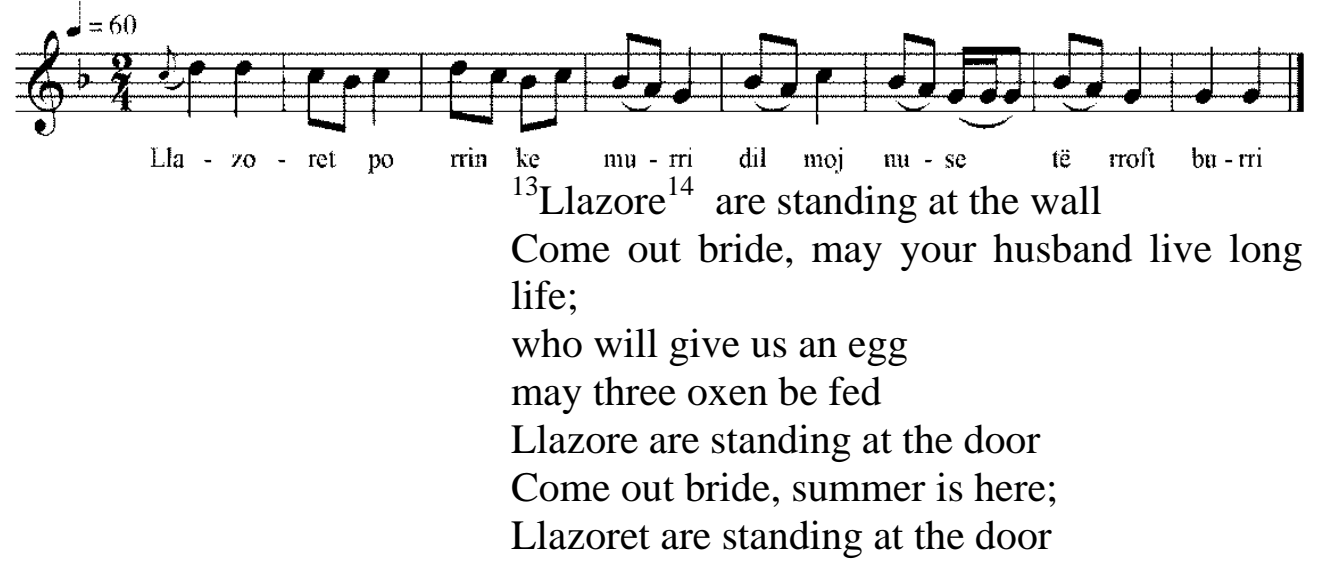

\footnotetext{
${ }^{12}$ FILJA Hysen, "Folk Songs of the central Albania”, The Science Academy of The Socialist Republic of the People of Albania, The Institute of the Folk Culture, "Mihal Duri" Press, Tirana 1991, f52, Song 17, Cassette 11051/14.

${ }^{13}$ The music is collected by H. Filja; Lyrics by M. Dule; written in notes by H. Filja.

${ }^{14}$ During the Llazore day small children would go door to door singing and the women would treat them.
} 
Come out bride, may your daughter live long life

Spotted rooster is singing,

Come out bride.

The intervals used in this song are: prima, minor second, major second and minor third. The extent is from note Sol $(G)$ on the second line, treble clef to note Re (D) on the fourth line, treble clef, comprising a range of a perfect fifth. The melody has mainly gradual motion but in both cases it overleaps in the minor third from the bottom of the staff - up. The melody has a melismatic character.

Mode:

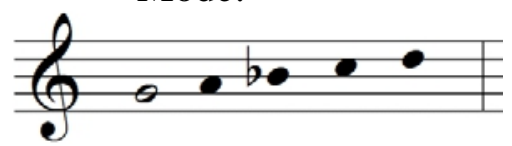

The cadence is sol-sol, but also we see that before the cadence there is a gradual descending from up-down. It is built on meter 2/4 and with a slow tempo of quarter-note, equals sixty, built mainly on two values of notes, quarter-notes and sixteenth-notes. The lyrics comprise two sentences of four measures each; one asks questions and the other answers. In this song where a strophe is made of ten lines, we find mainly the line with eight syllables, and the lines do not repeat. The rhyme used is AABB and we see that the hyperbole is used (may three oxen be fed), we also see the use of apostrophe, in function of the rhythm (rrin'(stay), dhont'(sheep), etc. Also, at the beginning of the lines we have reiteration (Llazoret po rrin') in three lines and (dil, moj nuse,) in four lines.

According to the publishing material where we found it, this song was sung by children and not by men in masks (men and children cover themselves with tree leaves and old clothes, so nobody will recognize them) as in the other songs about Llaxore.

Llaxore llaxore ${ }^{15}$

Ndoq, Tirana, 1964

Singer: Man

Bob. 293/26

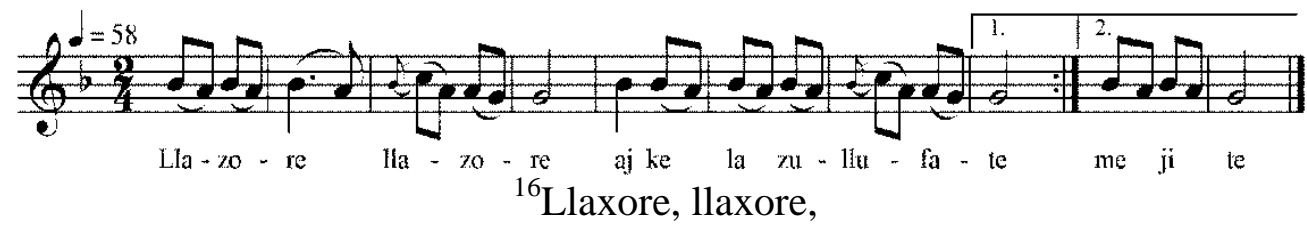

${ }^{15}$ FILJA Hysen, "Folk Songs of the central Albania”, The Science Academy of The Socialist Republic of the People of Albania, The Institute of the Folk Culture, "Mihal Duri” Press, Tirana 1991, f53, Song 18, Cassette 293/26. 
Did you wash quiff-e?

Who will give me one egg?

May he get a young bride.

Walking down on the fields

My pants were ripped off-e;

Walking down on the thorns-e

My moccasins ripped off-e.

Llaxore of March-e,

May the weather be warm-e.

The intervals used in this song are: prime, minor second, major second and minor third if we don't agree about the acciaccatura. But we can say that the intervals used are: prime, minor second and major second because the acciaccatura is part of the system too. The extent of this song reaches the clear fourth from note Sol on the second line to the note Do on the fourth intervening space. The Melody is mainly relied on notes si-la and only two times we see note Do and three times note Sol.

Mode:

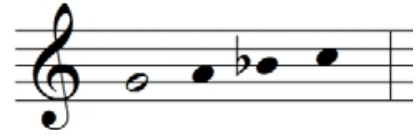

The cadence is gradual up-down la-sol, is built on a binary meter $2 / 4$ and with a very slow tempo, quarter-note equal to fifty-eighth-note. If we compare the partiture with the lyrics we find out that there are words in the partiture that are not in the lyrics and at the same time they have no meaning, words like "me ji te", these three syllables replace the last syllable of the word "zullufa-te (quaff)". Also we see that some words are not written the same in the partiture and in lyrics. For example: partiture (Llazore, zullufate), lyrics (Llaxore, xullufet-e). To understand this better we must hear the cassette recording, in order to give a more correct explanation. In this song we see that at the end of each lines is used the exclamatory "e", this way all the lines have the same rhyme at the end. The song has ten lines and the first line is the only one with six syllables, and all the others have seven syllables each. We see the repetition of the same word twice (Llaxore, llaxore) also the apocopa (gjat', baft', gris'), etc. Verses five and six are repeated twice too (tuj shëtit (while walking...), mu kan' gris'(has been ripped off).) The singer is asking for eggs, and is explaining how much he suffered to get there.

${ }^{16}$ The music was collected by M. Daiu, the lyrics by A. Mustawi, written in notes by $\mathrm{H}$. Filja. 
Llaxoret $^{17}$

Kashar 23.12.2014
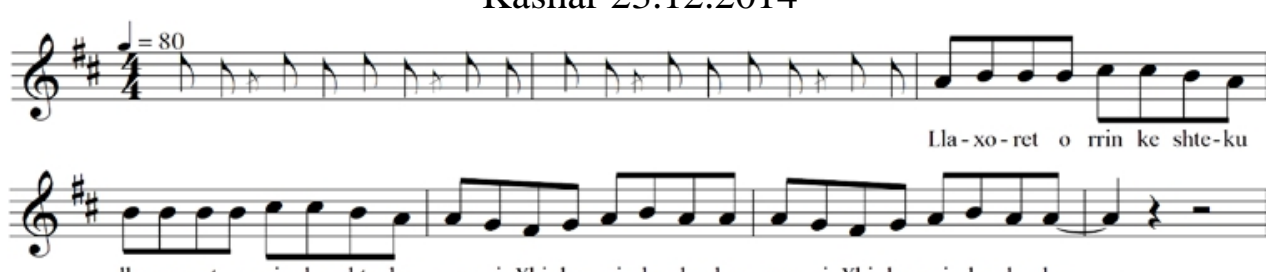
lla-xo-ret o rrin ke shte-ku çou oj Xhi-ke pri dy-she-ku çou oj Xhi-ke pri dy-she-ku
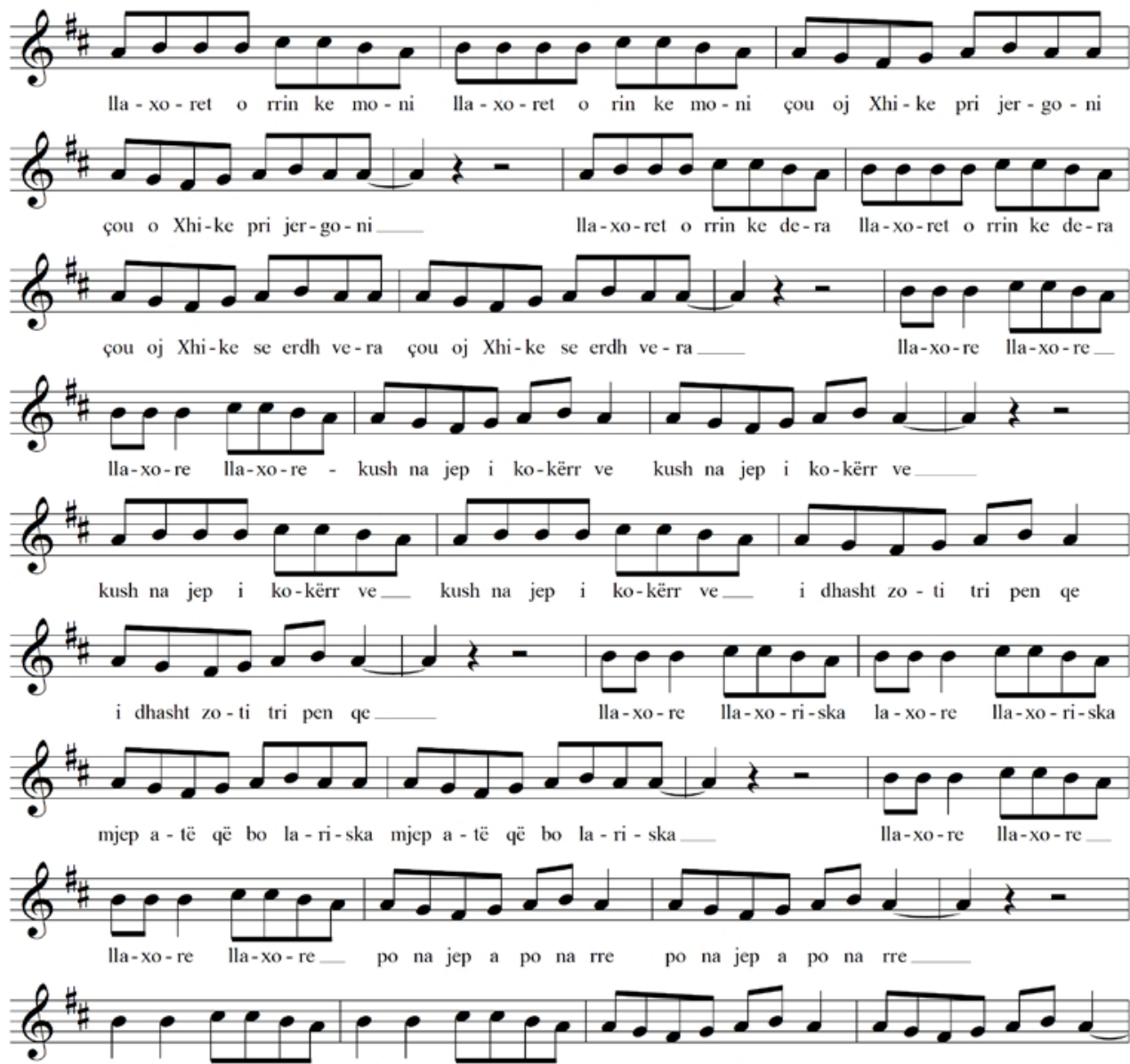
sa lesh m'a-ta desh sa lesh m'a-ta desh a-qi be-re-qet të kesh a-qi-be-re-qet të kesh

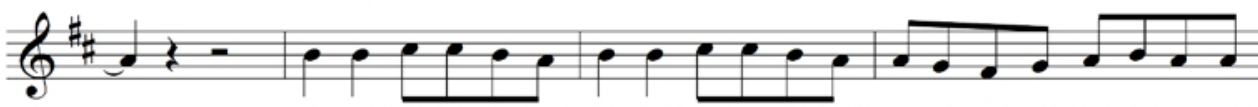

sa gjeth ka m'at ku-mull sa gjeth ka m'at ku-mull ne-sër gdhi-fshi gjith ga-rru-mull

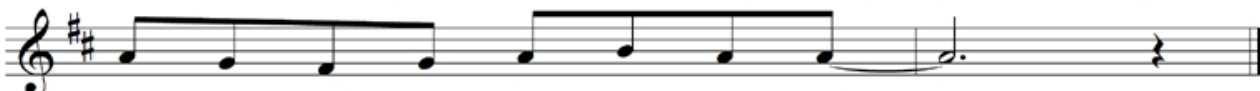

ne - sër gdhi - fshi gjirh ga - rru - mull

Singers: Male Choir

${ }^{17}$ Individual registration. CD Kashar. Song 4 
CD. Kashar. Song

Llaxore o stay at the path

Stand up oj Xhike from the bed

Llaxoret o stay under the mulberry

Stand up oj Xhike from the quilt

Llaxoret o stand at the door

Wake up oj Xhike summer is here blessings $^{18}$

Llaxore llaxore

tree

Who will give us one egg

Who will give us one egg

May God give him three oxen
Llaxore, llaxoriska

Give me what the chicken does

Llaxore, llaxore

Will you give it or you lied

May you have as much

As there is wool in a sheep

As there are leaves on the plum

May you all wake up sick ${ }^{19}$

(Lines are repeated twice each)

The story of llaxore: An old pagan celebration. This holiday would start at the beginning of summer and continue for ten days. During these days and nights six or seven men would gather and form a group which was called Llaxore. They would go out every night, go from one house to the other and sing the song dedicated to Llaxore.

According to the old tales Llaxore were half naked and would be disguised with leaves, paint their faces in black and put crowns made of bushes. Years later they started to wear old ladies clothes. Through the lyrics of the songs the Llaxore would ask for eggs, which were the symbol of this celebration and they refused to leave without getting what they were asking for, creating a nice and humorous situation. This ritual has been preserved for centuries until 1960, but then it was prohibited by the regime. ${ }^{20}$

The Intervals used in this song are: the perfect unison (prime), minor second and major second. The extent goes from note Fa\# in the first intervening space to note Do\# in the fourth intervening space reaching the fifth interval. The Melody of this song, though extents to the fifth, the widest interval found here is the major second because this melody is gradual without leaps and we find the repetition of the same note many times. The melodic structure is syllabic.

Mode:

\footnotetext{
${ }^{18}$ These lines were sung after receiving what they were asking for, the eggs

${ }^{19}$ These lines were sung after they received a bucket of cold water in the face instead of eggs.

${ }^{20}$ Individual registration CD Kashar, Song 4
} 


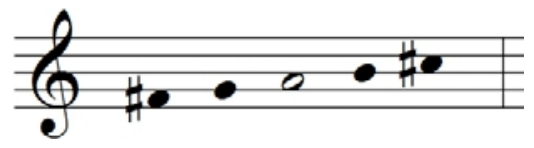

The cadence is la-la. The song has the meter $4 / 4$, and most of the time we see the eighth-note but some times the quarter-note too, which relates to a previous quarter-note or eighth-note making us feel the syncope.

The song is started by the percussive instrument, tambourine* (the first two measures) followed by the group of men accompanied by this instrument all the time. After every four measures the group makes a pause but the instrument continues the music.

Regarding the lyrics of the song, as simply as possible and by using rhyming words, the group of men asks the owner of the house to give them eggs. In the first strophe the rhyme is AABB and the line has eight syllables. In the other lines of the song we find lines with six, seven and even four syllables, while the last line again has eight syllables. At the second strophe all the lines have the same rhyme, while at the third and the fourth strophes we see again AABB.

\section{Conclusion}

These songs, just like other folk songs, are almost distinguished. We could find some areas that were using other folk songs but, the $\mathrm{ritual} /$ ceremonial songs are not used at all. They only live in the memories of old people who sing them only on a special occasion, just like happened for the song 'Llaxoret' which was found during the research for the National Folk Festival, Gjirokastra 2015.

There were six songs that we studied for this study, but only one of them has an individual cassette recording (I recorded this song during my study), the song "Llaxoret". The other songs were recorded before by other authors. These songs have been forgotten with the passing of the time, and have been covered by the dust of the years.

From all these six songs, three of them are built on a single pitch-this means that they are recited more than sang-, and we might say that these songs have mostly a recitative character; two of the other three songs have intervals from prime to minor third, while the third one has an interval from prime to the major second. The range in two of them goes to the fifth and for the other one in a perfect fourth.

The melodies of these songs don't have many leaps. Those are built mostly on gradual motion especially in the last song "Llaxoret". Most of the time the melody is syllabic, only in two songs it tends to be melismatic, except for the song "Llaxoret" and the monophonic songs, all the rest have a minor character. 
Mode used in these two songs is thought to be the Aeolian. At the last song "Llaxoret" we suggest the mode is Ionian. There is no cadence in three of the songs, but at the other two the cadence it has been done in the same note while at the other one it has been done gradually from up down.

The meter used mostly is $2 / 4$ and we find it in four of six songs that we are studying. We use the meter $4 / 4$ which has the same character, but we see also the meter $9 / 8$ at "O shëngjergj i nushullu". The rhythm of these materials is really simple and there aren't difficult figures of speech. Most of the time we find the eighth-notes and quarter-notes, and only few times a sixteenth-note only to help with the syllables of the lyrics.

In this group of songs we find different variations of the 'llaxore' ritual, and see also that in some songs it is written Llaxore with an " $x$ " and in some others Llazore with " $z$ ". For this study we only found three variations of this song, but we believe that there are more variations in these villages.

Most of the time these songs have few lines each with different number of syllables, except for the three songs of Llaxore who have more lines with almost the same number of syllables per line. In some of the songs we find words used in dialect and also some figures of speech as: apocope, hyperbole, anaphora, etc. In the cradle songs we saw often the exclamation "o", but here we find more the exclamation "e": "Llaxore, llaxore".

These songs talk about the coming of spring, summer, etc. Besides the primary meaning, there are hidden meanings as well, like the song "Marsi Karsi".

*The Albanian tambourine

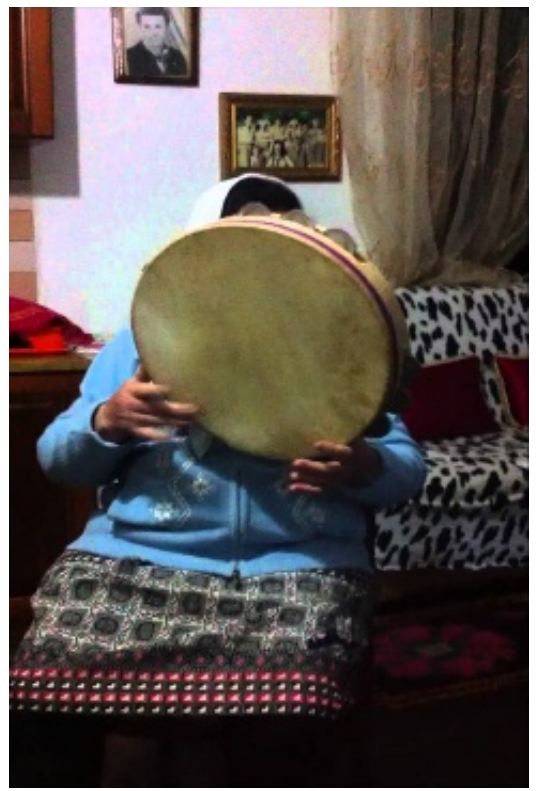


THE MAP OF THE AREA WHERE THIS STUDY WAS DONE
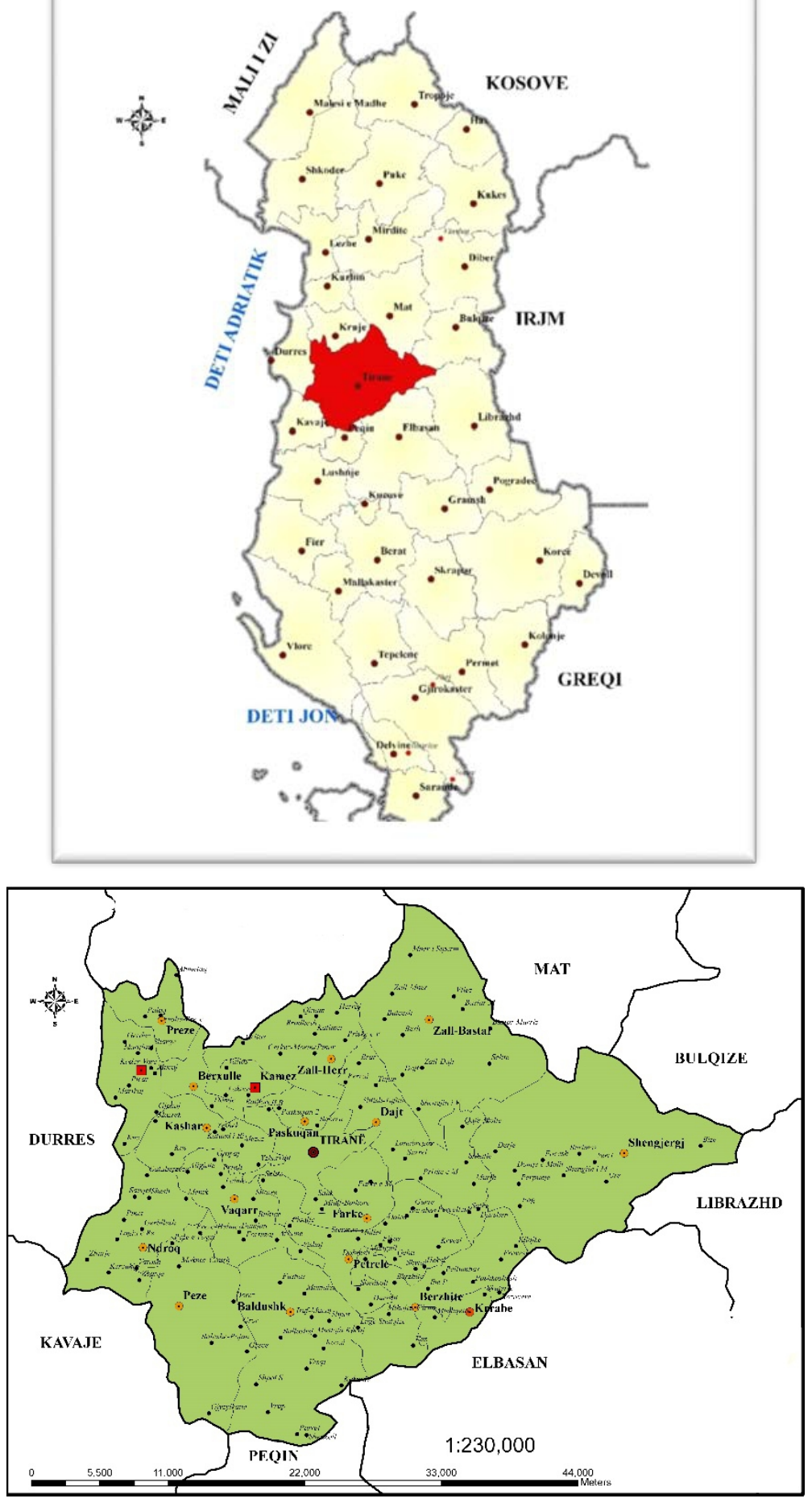


\section{References:}

BARNET Sylvian., BELLANCA Pat.,STUBBS Marcia., “Academic Writing”, Dita, Tirana, 2000.

FILJA Hysen, "Folk Songs of the central Albania”, The Science Academy of The Socialist Republic of the People of Albania, The Institute of the Folk Culture, "Mihal Duri” Press, Tirana 1991

GJINARI Jorgji., SHKURTAJ Gjovalin., "Dialectology”, SHBLU, Tirana, 2009.

HAXHIHASANI Qemal., VASILI Kozma., "Ritual and work songs”, "Folk Lyrics", Vol I, The Science Academy of The Socialist Republic of the People of Albania, The Institute of the Folk Culture, Tirana, 1988.

SOKOLI Ramadan, "Albanian Musical Folklore" (Morphology), Folklore Institute, Tirana, 1965.

SHUPO Sokol., “Albanian Musical Folklore”, Vol.I. ASMUS, Tirana, 2002. TOLE Vasil.S, “Albanian musical folklore”, Iso polyphony and Monody, “Uegen”, Tirana, 2007.

XHAGOLLI Agron., "Etnology and Albanian Folklore”, "Ismail Qemali" University, Faculty of Education, Albanian Language and Literature, Triptik, Vlora, 2007.

ZHEJI Gjergj., Albanian Folklore, Argeta LMG, Tirana, 1998.

www.fjalorishqip.com

www.gazetadielli.com, HABAZAJ. Albert. R., A mythological look on the traditional yearly celebrations and ritual lyric, 13 Mars 2014. 